\title{
Economic Performance and Factors Affecting The Context Socio Economic Environmental Accounting (SEEA)
}

\author{
Heri Widodo \\ Program of Accounting Science \\ Universitas Airlangga Surabaya \\ Surabaya, Indonesia \\ Faculty of Economics and Business \\ Universitas Muhammadiyah \\ Sidoarjo, Indonesia \\ heriwidodo@umsida.ac.id
}

\begin{abstract}
This study aims to determine the effect of Environmental Performance on Economic Performance at Pharmaceutical companies in Indonesia, used Predeterminated Variable. This research type is quantitative approach, with the population 10 Pharmaceutical companies listing in Indonesia Stock Exchange. The Period of observation is in 2014-2016. The result of the research shows that Environmental Performance has an effect on Economic Performance by including Unexpected Earnings, Profit Margin, Environmental Concern, Firms Size, and Ownership as control variables.
\end{abstract}

Keywords- economic performance, environmental performance, socio-economic environmental accounting

\section{INTRODUCTION}

The company was established with the aim of maximizing the value of the company. The concept of maximizing the value of this company will have an impact on the orientation of the company cannot be on profit maximization, only think about the interests of the owner or management, but also concern to all related parties, such as employees, consumers, and society and the environment. In line as proposed [1], that the existence of a company cannot be separated from the interests of various parties.

Companies wishing for business sustainability should also take account of this environmental aspect, as well as companies engaged in the pharmaceutical industry. Companies in this sector should concern and make the full disclosure because the company is in operation to produce an impact of the environment.

The concept of green accounting developed since the 1970s in Europe. This development was followed by studies related to the issue of green accounting in the 1980s ( [2]; [3] ). Other terms for green accounting are an environmental accounting [4], Sustainability Accounting [5], or Environmental Accounting Disclosure [6]. The concept of social and environmental accounting discourse has led to the concept of Socio-Economic Environmental Accounting (SEEA) which is a brief explanation of the definition of Triple Bottom Line [7], wherein it's financial reporting, the company reports the performance of its operational activities, environmental performance, and social performance [8].

Empirical research on the relationship between environmental performance, economic performance, and environmental disclosure, in general, has considered the strength of the relationship between these variables. Nevertheless, some studies show contradictory results [9]. Reference [10] found no significant relationship in testing the relationship between environmental disclosure and environmental performance. Reference [11] found a negative relationship between environmental disclosure in annual reports and environmental performance. Meanwhile, [12] found a significant positive relationship between economic performance with environmental performance as well as between environmental disclosure and environmental performance. Moreover, some researchers questioned the quality of information conveyed in the disclosure of the environment. Studies in Australia show a gap between environmental disclosure and environmental performance. The findings prove that the quality of disclosure is inadequate. Other studies have also found evidence that firms tend to disclose things well and retain environmental information that adversely affects the company's reputation, as it assumes that bad news can dampen investor confidence in the company and can degrade the company's economic performance. These studies show still contradictory results [9] in [13]. Based on this understanding, this study aims to determine the effect of Environmental Performance on Economic Performance at Pharmaceutical companies listing in Indonesia Stock Exchange, by including Predeterminated Variable.

\section{Triple Bottom Line}

This concept recognizes that if the company wants to be sustain it is necessary to concern to $3 \mathrm{P}$, which is not only hunting the profit, but also should contribute to the society (people) and active in preserving the environment (planet) as proposed by John Eklington in [14]. Thus, the community has a strong interrelation in order to create value for the company. Almost impossible, the company 
is able to run operations in a sustainable manner without the support of the surrounding community. Therein lies the most important of the willingness and ability of the company closer to the community through the strategy of social obligation [14].

\section{Legitimacy Theory}

The theory of legitimacy states that the company continuously acts according to norms and limits in society, for its enterprise hopes that its activities are supported by society (Deegan in [15]. The realization of legitimacy in the business world can be the report of social and environmental activities of the company. Reference [16] explain the conflict of interest in agency relations due to the different goals of managers and owners of companies in the short and long-term [15]. Reference [17] argue that legitimacy can be obtained when there is conformity between the existences of the company is not disturbing or congruent with the existence of the existing value system in society and environment. When there is a shift leading to nonconformity, then the company's legitimacy can be threatened. As a result, companies should seek to establish and maintain their legitimacy in the community by carrying out environmental responsibility and public disclosure to the public in financial reporting ( [17]; [18]).

\section{Stakeholder Theory}

The company is not only responsible to the owners (Shareholder) as it happens so far, but shifted to a wider range in the social sphere (stakeholder), furthermore referred to as social responsibility. This phenomenon occurs, because of the demands of society due to negative externalities that arise and social inequality that occurred [19]. To that end, the responsibility of the company that was originally only measured on economic indicators (economic-focused) in the financial statements, must now shift by taking into account social factors (social dimensions) to stakeholders, both internal and external. Corporate social disclosure is a successful means for companies to negotiate relationships with their stakeholders [20].

\section{Green Accounting}

Accounting grows and develops in a society that is also growing. Its existence is not free of value against the development of the period. Methods of accounting introduced by Luca Pacioli at that time deemed to be sufficient and adequate because able to solve the problem of reporting and business accounting is needed at this time, however, when the complexity of the business is getting higher, the necessary methods of measurement, recognition, and reporting of the more advanced [21]. As a result, accounting continues to evolve and match the needs of his time.

When the movement of environmental care (green movement) developed, the accounting is also ready with these developments, so that born the term green accounting or environmental accounting. Similarly, when some industries began to show social awareness, then emerged social accounting discourse (social responsibility accounting). Since understanding accounting as part of the service function of either social, cultural, economic and even political, then many factors affect the accounting itself.

Reference [22] explain that culture is the main factor affecting the development of business structure and social environment, which will ultimately affect accounting. The consequences of this social and environmental accounting discourse eventually led to the concept of SocioEconomic Environmental Accounting (SEEC), which is actually a brief explanation of the definition of Triple Bottom Line [7] where accounting reporting to the public includes not only economic performance but also environmental performance and social.

\section{Environmental Performance}

Reference [9] stated that environmental performance is the company's performance in creating a good environment (green). The measurement of environmental performance is an important part of the environmental management system. It is a measure of the result of the environmental management system given to the company in real and concrete terms. In addition, environmental performance is a measurable outcome of the environmental management system, which is linked to the control of its environmental aspects. The assessment of environmental performance is based on environmental policy, environmental objectives and environmental targets (ISO 14004, from ISO 14001).

In Indonesia, the Environmental Assessment Performance Rating was developed by the State Ministry of the Environment as an alternative to compliance instruments since 1995. PROPER intends that stakeholders can actively address this level of compliance information, and encourage companies to further improve management performance the environment. Hence, in the end, the environmental impact of the company's activities can be minimized. In other words, PROPER is a Public Disclosure Program for Environmental Compliance.

\section{Environmental Disclosure}

Disclosure is generally divided into two types namely, voluntary disclosure and mandatory disclosure. Voluntary disclosure is the disclosure of various information related to voluntary corporate activities/circumstances. Although in fact, voluntary disclosure does not really occur because there is a tendency for companies to store intentionally information that can reduce cash flow. It is considered to cause harm to the company. Therefore, managers of a company will only disclose good information that can benefit the company.

Reference [23] argue that the company will disclose all the necessary information in the course of the functioning of the capital market. The proponent of the opinion states that if information is not disclosed this is because the information is irrelevant to the investor or the 
information is already available elsewhere. Environmental disclosure is the disclosure of environmental related information in the company's annual report. It is generally located in a separate section of the Sustainability Report or listed in the Annual Report. In America, the SEC is responsible for disclosure-level issues and the disclosure format is a FASB task. While in Indonesia, which has mandatory disclosure authority is Bapepam.

\section{Economic Performance}

According to [9] economic performance is the macroeconomic performance of a group of companies in an industry. The measurement of economic performance can be calculated according to accounting based measures as well as capital market-based. In accounting, based measures can use financial ratio analysis as a financial measurement. In previous research, [8] used accountingbased measures (earnings per share and ROE). While Spicer in [12] use both accounting based measures and capital market based (profitability and price earning ratio).

\section{Hypothesis \\ H1: Environmental Performance effect on Economic Performance on Pharmaceutical companies listing on Indonesia Stock Exchange}

\section{METHODS}

This research is conducted on pharmaceutical companies listed on Indonesia Stock Exchange in 20142016. The variables in this study are:

Dependent variable: Economic performance.

Economic performance is the performance of firms relative to the same industry characterized by the industry's annual return. According to [12] in [9] economic performance stated in:

$$
E P=\frac{\left[F_{1}+P_{0}\right]+D i w}{P_{0}}-M e R I
$$

$\mathrm{P} 1=$ year-end stock price,

$\mathrm{P} 0=$ stock prices earlier in the year,

Div $=$ dividend payout, $\backslash$

MeRI = median return industry the industry return is measured by the industry index obtained from the Indonesian Stock Exchange (IDX)

Independent variables include Environmental Performance Variables, and Predeterminated Variables (Unexpected Earnings, Profit Margin, Environmental Concern, Firms Size, and Ownership).

a. Environmental Performance

Environmental Performance according to [9] is the company's performance in creating a good environment (green). The company's environmental performance is measured by the achievement of the company following the PROPER program, which is one of the efforts undertaken by the Ministry of the Environment, which includes rating the company in 5 colors, and scored 5 consecutively for gold color and lowest 1 for black color.

b. Predeterminated Variable

The Predeterminated variable is the control variable whose value has been obtained first before calculating the value of the endogenous variable [9]. Predeterminated variables set out in this study were measured as in the description below.

i. Unexpected Earnings, measured by the annual change in earnings per share divided by the stock price at the beginning of the period.

ii. Profit Margin, measured from the ratio of net income to net sales to reveal the profitability and competitive market presence.

iii. Environmental Concern, measured by the company's participation in the ISO 14000 series certification program, obtained from the Ministry of Environment database and other sources. Environmental Concern is measured using Environmental Concern scoring, if the company participates in following ISO 14000 series certification then it is given a score of 1 , otherwise, it will be scored 0 .

iv. Firm Size, measured from total assets which then transform the total asset data into natural logarithm (Ln).

v. Ownership, measured by the type of capital of the company, namely PMA, PMDN, and SOE. PMA with value 1, PMDN with value 2 , and SOE with value 3 .

\section{Population and Sample}

The population in this study is a pharmaceutical company listed on the Indonesia Stock Exchange in the period 2014-2016, some 10 companies. The technique of determining the sample using saturated sampling technique, so that the whole population used as a sample [24].

\section{Hypothesis Testing}

In this research, the model of multiple linear regression hypothesis testing is as follows:

Economic performance $=($ Environmental performance + Predeterminated variable)

EconP $=\alpha+\beta 1$ EnvrP $_{\text {it }}+\beta 2$ ProfM $_{\text {it }}+\beta 3$ FirmS $_{\text {it }}+\beta 4$ Owner $_{\text {it }}+\beta 5$ EnvrC $_{\text {it }}+\beta 6$ EnexC $_{\text {it }}+C$---------------------(2)

\section{RESULT AND DISCUSSION}

Taking into account the results of this study in Table 1, using the help of statistical tools SPSS obtained results that the level of significance value is of 0.04 . This value is smaller than the predefined fault tolerance of $5 \%$. Based on these results can be concluded that the proposed hypothesis can be accepted, that the Environmental Performance variable affects the Economic Performance on Pharmaceutical companies listing on the Indonesia Stock Exchange. 
TABLE 1 ANOVA ANOVA $^{\mathrm{D}}$

\begin{tabular}{|l|c|r|r|c|r|}
\hline \multicolumn{1}{|l|}{ Model } & $\begin{array}{c}\text { Sum of } \\
\text { Squares }\end{array}$ & df & Mean Square & F & Sig. \\
\hline $1 \quad$ Regression & $9.998 \mathrm{E} 17$ & 6 & $1.666 \mathrm{E} 17$ & 4.423 & $.004^{\mathrm{a}}$ \\
Residual & $8.666 \mathrm{E} 17$ & 23 & $3.768 \mathrm{E} 16$ & & \\
\multicolumn{1}{|c|}{ Total } & $1.866 \mathrm{E} 18$ & 29 & & & \\
\hline
\end{tabular}

a. Predictors: (Constant), UnexE, ProfM, EnvrC, EnvrP, Owner, Firms

b. Dependent Variable: EconP

The results of this study are in line with the research that has been done by [12] found a significant positive relationship between economic performance with environmental performance as well as between environmental disclosures with environmental performance. Similarly, research conducted by [11] although the findings is having a negative relationship between environmental disclosures in an annual report with environmental performance. At the same time, the results of this study support the theory that has been developed previously, both the theory of the Triple Buttom Line, Theory of Legitimacy, and Stakeholder Theory. This shows that the sustainability of a company cannot be separated from various interests, including the interests of the environment. Regardless of the regulations on the disclosure of the environment by the company, various parties who interested with the company will see and pay attention to companies that are committed to the environment.

\section{CONCLUSION}

Based on these results, can be concluded that the proposed hypothesis can be accepted, that the Environmental Performance variable affects the Economic Performance on Pharmaceutical companies listing on the Indonesia Stock Exchange.

\section{ACKNOWLEDGEMENT}

I Thanks to Universitas Muhammadiyah Sidoarjo for supporting this research.

\section{REFERENCES}

[1] Kusumaningtyas, Rohmawati, "Green Accounting, Mengapa dan Bagaimana?," in Proceeding Seminar Nasional dan Call for Paper Sancall 2013, Surakarta, Jawa Tengah, 2013.

[2] Bebbington, J., "Engagement, education, and sustainability," Accounting, Auditing \& Accountability Journal, vol. 10, no. 3, pp. 365-381, 1997.

[3] Gray, R., Kouhy R., dan Lavers, S., "Methodological Themes: Constructing A Research Database of Social and Environmental Reporting By UK Companies," Accounting, Auditing and Accountability Journal, vol. 8, pp. 78-101, 1995b.

[4] Yakhou, Mehenna and Vernon P. Dorweiler, "Environmental Accounting: An Essential Component of Business Strategy,"
Business Strategy and the Environment, vol. 13, p. 65-77, 2004.

[5] McHugh, J. , "Accountants have key role in sustainability," Academic Research Library, 2008.

[6] Lindrianasari, "Hubungan antara Kinerja Lingkungan dan Kualitas Pengungkapan Lingkungan dengan Kinerja Ekonomi Perusahaan di Indonesia," Jurnal Akuntansi dan Auditing Indonesia, vol. 11, no. $2,2007$.

[7] Wiedmann, T. and Manfred, L., "Third Annual International Sustainable Development Conference Sustainability - Creating the Culture," pp. 15-16, 2006.

[8] Milne, M.J. and Ralph, W. A. , "Exploring the reliability of social and environmental disclosures content analysis," Accounting, Auditing \& Accountability Journal, vol. 12, no. 2, p. 237, 1999.

[9] Suratno, Darsono, dan Siti Mutmainah, "Pengaruh Environmental Performance Terhadap Environmental Disclosure Dan Economic Performance: Studi Empiris Pada Perusahaan Manufaktur Yang Terdaftar Di Bursa Efek Jakarta Periode 2001-2004," in Simposium Nasional Akuntansi IX, Padang, 2006.

[10] Ingram, R. dan Frazier, K. , "Environmental Performance and Corporate Disclosure," Journal of Accounting Research, vol. 18, pp. 612-622, 1980.

[11] Patten, D.M. , "The Relation Between Environmental Performance and Environmental Disclosure: a Research Note," Accounting, Organizations and Society, vol. 27, p. 763-773, 2002.

[12] Al-Tuwaijri, S.A., Christensen, T.E. dan Hughes II, K.E. , "The Relations among environmental disclosure, environmental performance, and economic performance: a simultaneous equations approach," Accounting, Organizations and Society, vol. 29, pp. 447-471, 2004.

[13] Almilia, Luciana Spica dan Wijayanto, Dwi, "Pengaruh Environmental Performance Dan Environmental Disclosure Terhadap Economic Performance," in Proceedings The 1st Accounting Conference, Depok, Jakarta, 2007.

[14] Nurfajriyah, "Implementasi Konsep Triple Bottom Line pada PT. Pertamina (Persero).," 2010.

[15] Oktariani, Ni Wayan dan Ni Putu Sri Harta Mimba, "Pengaruh Karakteristik Perusahaan dan Tanggung Jawab LIngkungan pada Pengungkapan Tanggung Jawab Sosial Perusahaan," E-Jurnal Akuntansi Universitas Udayana, vol. 6, no. 3, pp. 402-418, 2014.

[16] Jensen, M, C, and Meckling, "Theory of the Firm: Managerial Behavior, Agency Costs dan Ownership Structure," Journal of Financial Economics, vol. 3, pp. 305-360, 1976.

[17] Dowling, J., \& Pfeffer, J., "Organizational legitimacy: social values and organizational Behavior," Pacific Sociological Review, vol. 18, no. 1, pp. 122-136, 1975.

[18] Lindblom, C.K, "The implications of organizational legitimacy for corporate social performance and disclosure.," Working Paper for the American Accounting Association Public Interest Section. , 
USA, 1994.

[19] Harahap, Sofyan Syafri, Teori Akuntansi. Edisi Revisi, Jakarta: Raja Grafindo Persada, 2002.

[20] Roberts, Charles, "Environmental Disclosures: A Note on Reporting Practices in Mainland Europe," Accounting, Auditing and Accountability, vol. 4, pp. 62-7, 1992.

[21] Utomo, Wacana Akuntansi Alternatif, Aksamala Institute, 2001.

[22] Belkaoui, A. R., and Picur, Ronald D. , "Cultural determinism and the perception of accounting concepts," The International Journal of Accounting, vol. 26, pp. 118-130, 1991.
[23] Ghozali, I dan Chariri, A, Teori Akuntansi, Semarang: Badan Penerbit UNDIP, 2007. 